\title{
Application of cornmeal at ensiling of alfalfa cocksfoot and their mixture
}

\author{
Jasmina Knežević, Miroljub Aksić, Slavica Ćirić \\ University of Priština, Faculty of Agriculture, Lešak, Serbia \\ Vladeta Stevović, Dalibor Tomić \\ University of Kragujevac, Faculty of Agronomy, Čačak, Serbia \\ Rade Stanisavljević \\ Institute for Plant Protection and Environment, Beograd, Serbia
}

\begin{abstract}
One of the solutions for the economical use of alfalfa and cocksfoot is making the silage. However, these plant species are difficult to be conserved without appropriate additives. The aim of this study was to determine the impact addition of cornmeal on the quality of silage of alfalfa (Medicago sativa L.) cv. Kruševačka 22, cocksfoot (Dactilys glomerata L.) cv. Kruševačka 40 and their mixture $(50 \%$ alfalfa, $50 \%$ cocksfoot). Mowing both species was carried out at the stage when $1 / 3$ to $1 / 5$ of the plants were in flowering in alfalfa or in stage appearance of inflorescence with cocksfoot. Corn grain is ground at the mill with a sieve $\varnothing 2 \mathrm{~mm}$, then mixed with chopped fodder of alfalfa, cocksfoot and the mixture in the following amount: 6\% (treatment A2), 3\% (treatment A1), and without cornmeal addition (control A0). After six months was determined silage quality. Cornmeal addition, according to the basic indicators of the quality of silage had a significant impact on changing the quality silage of alfalfa, cocksfoot and their mixtures.
\end{abstract}

Received: 06. 09. 2014. / Accepted: 20. 12. 2014. 
It is evident that the addition cornmeal addition a significant impact on increasing the energy value (primarily the content inside BEM) of silage in all studied treatments.

Key words: silage, alfalfa, cocksfoot, cornmeal, quality.

\section{Introduction}

In the region of Southeast Europe alfalfa is the most important perennial forage legume that is grown on about 320 thousand hectares in Romania (Moga and Schitea 2005), on 200 thousand hectares in Serbia (Stanisavljević and Beković 2012), on 160 thousand hectares in Bulgaria (Vlahova et. al. 2005), on 40-50 thousand hectares in Croatia (Stjepanović and Popović 2009).

Cocksfoot is a forage grass of greater importance in arid areas (Probert et al. 1986, Ruzić et al. 2011). In preparing legume forage mixtures, alfalfa and cocksfoot are the basis significantly influencing the achievement of high yields of quality forage (Samuil et al. 2011).

In this region fodder is mainly dried after mowing, hay is prepared and it is used in the nutrition as such.

With the classic application the first cutting in these plants is in May and accounts for about $50 \%$ of the total annual forage yield. At the time of harvest rainfalls are frequent, temperatures are relatively low with high humidity in the air and drying hay is made more difficult and sometimes damaging occurs. On the other hand making silage is less under the influence of unfavorable weather conditions, losses are lower and forage quality is better (McDonald et al. 1991).

The greatest obstacle to successful alfalfa silage and partly of perennial grasses silage is insufficient amount of sugar. In practice, for this purpose, mainly used as feed additives are carbohydrate feed (corn meal or barley, dried beet pulp, etc.). However, in years with reduced yield of corn, barley and other grains, such additions are quite expensive and researches for finding a minimum but sufficient amount of carbohydrate nutrients for the production of as cheap as possible silage while maintaining the required quality are unavoidable.

Therefore, the goal of this study was finding the optimal application of corn meal for ensilage of alfalfa, cocksfoot and their mixture (50\% of alfalfa : $50 \%$ of cocksfoot) and the impact on quality of ensiled forage.

\section{Materials and methods}

The study was conducted at the forage of: alfalfa (Medicago sativa L.) Kruševačka 22 cultivar, cocksfoot (Dactilys glomerata L.) Kruševačka 40 cultivar, and on the mixture (50\% of alfalfa and $50 \%$ of cocksfoot). Mowing of both species was carried out at the stage when $1 / 3$ to $1 / 5$ of the plants were in flowering regarding alfalfa and cocksfoot at tillering. 
Corn grain was ground in a mill with ø $2 \mathrm{~mm}$ diameter sieves, then mixed with chopped fodder of alfalfa, cocksfoot and the mixture in the amounts of: $6 \%$ (treatment A2), 3\% (treatment A1), and without the meal (control A0).

After six months the silage quality was determined according to the standard methodology:

- dry matter $\left(\mathrm{DM} \mathrm{g} \mathrm{kg}^{-1}\right)$ by drying in a dryer at a temperature of $65^{\circ} \mathrm{C}$. Quality of dry matter (chemical composition) is determined by the "WEENDE" analysis system.

- crude ash content $\left(\mathrm{g} \mathrm{kg}^{-1}\right)$ - by the method of dry ashing at $550{ }^{\circ} \mathrm{C}$;

- crude protein content $\left(\mathrm{g} \mathrm{kg}^{-1}\right)$ - by Kjeldahl method, modification according to Bremner;

- fat content $\left(\mathrm{g} \mathrm{kg}^{-1}\right)$ - by Soxhlet method, modification according to Ruskovski; - cellulose content $\left(\mathrm{g} \mathrm{kg}^{-1}\right)$ - according to Weende method;

- NFE $\left(\mathrm{g} \mathrm{kg}^{-1}\right)$ - by subtracting the values of the aforementioned parameters from 1000 ;

- nitrogen free extractives (NFE) were determined by calculation;

- total mineral matter content (crude ash-SPe) was determined quantitatively;

- the content of calcium $(\mathrm{Ca})$ was determined by AAS with the addition of salt of lanthanum due to control ionization, using complexometric method;

- the content of phosphorus (P) is determined according to standard ISO 6491 method with the molybdenum-vanadate reagent spectrophotometrically.

For the determination of differences between treatments the Tukey test $(\mathrm{P} \leq 0.05)$ was applied.

\section{Results and Discussion}

Properties of an ideal forage plant for conservation in the form of silage is when the FC content is greater than $250 \mathrm{~g} \mathrm{~kg}^{-1}$ with adequate sugar minimum. Alfalfa and partly forage grasses as well fall into fodder plants that are very difficult ensilaged due to the low sugar content which causes the creation of a small amount of lactic acid. The result of it is a high $\mathrm{pH}$ value, which cannot prevent butyric fermentation. At the same time, intensive decomposition of proteins and amino acids occurs, the $\mathrm{pH}$ of silage increases again and the silage is unstable and short-lived. However, addition of feedstuffs rich in carbo-hydrate content successfully overcome these problems and a stable silage is obtained (Šćiban et al 2013).

As carbohydrate nutrient in the experiments and practice the most commonly used is cornmeal (Pavlićević et al. 1999; Djordjević et al. 2000). Corn is anyway an ideal plant for silage (Terzić et al. 2013). 
Handžić et al. (1972) ensilaged the alfalfa with the addition of ground corn $(20,25$, and $32 \%)$ and comminuted whole corn cobs $(18,20$, and $27 \%)$ and obtained stable and quality silage. According to Carino (1988), ensiling alfalfa dry matter should be raised by carbohydrate nutrients to the optimal value of 30$40 \%$ and the minimum sugar content should also be raised.

In our studies, with the application of $6 \%$ of corn meal dry matter was increased by $37 \mathrm{~g} \mathrm{~kg}^{-1}$, as well as the application of $3 \%$ of corn meal dry matter was increased by $14 \mathrm{~g} \mathrm{~kg}^{-1}$ (Table 1). On the other hand the content of MM ( $\mathrm{g} \mathrm{kg}^{-}$ $\left.{ }^{1} \mathrm{DM}\right)$ in the treatment with the application of the $6 \%$ of corn meal was significantly $(\mathrm{P} \leq 0.05)$ lower as compared to the use of $3 \%$ of corn meal, whereas between the treatment $\mathrm{A} 1$ and $\mathrm{A} 0$, the difference was $2.9 \mathrm{~g} \mathrm{~kg}^{-1}$ of DM and was not statistically significant. Addition of cornmeal as a carbohydrate nutrient also influenced the CP reduction of $19 \mathrm{~g} \mathrm{~kg}^{-1} \mathrm{DM}$, statistically significant differences have been found $(\mathrm{P} \leq 0.05)$, both between the treatments $\mathrm{A} 0$ and $\mathrm{A} 1$ and between $\mathrm{A} 1$ and $\mathrm{A} 2$ treatment. Addition of $6 \%$ cornmeal in the silage significantly affected $(\mathrm{P} \leq 0.05)$ the content of $\mathrm{CF}\left(\mathrm{g} \mathrm{kg}^{-1} \mathrm{DM}\right)$ in $\mathrm{A} 1$ treatment whereas between treatments $\mathrm{A} 1$ and $\mathrm{A} 0$ statistically significant difference was not found. As expected corn meal affected the increase of NFE $\left(\mathrm{g} \mathrm{kg}^{-1} \mathrm{DM}\right)$ and the increase in $\mathrm{P}\left(\mathrm{g} \mathrm{kg}^{-1} \mathrm{DM}\right)$, while $\mathrm{Ca}\left(\mathrm{g} \mathrm{kg}^{-1} \mathrm{DM}\right)$ content was decreased.

Table 1 - Content of nutritive matters of alfalfa silage

\begin{tabular}{ccccc}
\hline \multirow{2}{*}{ Property } & \multicolumn{3}{c}{ The level ground maize (\%) } & \multirow{2}{*}{ Average } \\
\cline { 2 - 4 } & $0(\mathrm{~A} 0)$ & $3(\mathrm{~A} 1)$ & $6(\mathrm{~A} 2)$ & \\
\hline $\mathrm{DM}\left(\mathrm{g} \mathrm{kg}^{-1}\right)$ & $330^{\mathrm{b}}$ & $342^{\mathrm{b}}$ & $367^{\mathrm{a}}$ & 346.3 \\
$\mathrm{MM}\left(\mathrm{g} \mathrm{kg}^{-1} \mathrm{SM}\right)$ & $103.3^{\mathrm{a}}$ & $100.4^{\mathrm{a}}$ & $85.4^{\mathrm{b}}$ & 96.3 \\
$\mathrm{CP}\left(\mathrm{g} \mathrm{kg}^{-1} \mathrm{DM}\right)$ & $185.8^{\mathrm{a}}$ & $175.9^{\mathrm{b}}$ & $166.2^{\mathrm{c}}$ & 175.9 \\
$\mathrm{CC}\left(\mathrm{g} \mathrm{kg}^{-1} \mathrm{DM}\right)$ & $339.7^{\mathrm{a}}$ & $300.0^{\mathrm{b}}$ & $290.6^{\mathrm{c}}$ & 310.1 \\
$\mathrm{CF}\left(\mathrm{g} \mathrm{kg}^{-1} \mathrm{DM}\right)$ & $36.4^{\mathrm{b}}$ & $38.7^{\mathrm{b}}$ & $43.9^{\mathrm{a}}$ & 39.7 \\
$\mathrm{NFE}\left(\mathrm{g} \mathrm{kg}^{-1} \mathrm{DM}\right)$ & $333.7^{\mathrm{c}}$ & $375.1^{\mathrm{b}}$ & $404.0^{\mathrm{a}}$ & 370.9 \\
$\mathrm{Ca}\left(\mathrm{g} \mathrm{kg}^{-1} \mathrm{DM}\right)$ & $19.6^{\mathrm{a}}$ & $19.0^{\mathrm{a}}$ & $17.0^{\mathrm{b}}$ & 18.5 \\
$\mathrm{P}\left(\mathrm{g} \mathrm{kg}^{-1} \mathrm{DM}\right)$ & $2.8^{\mathrm{c}}$ & $3.0^{\mathrm{b}}$ & $3.2^{\mathrm{b}}$ & 3.0 \\
\hline
\end{tabular}

The determined difference between treatments was expressed by the letters $a, b, c$ using the Tukey test at a $5 \%$ probability level.

In relation to silage made from alfalfa, the cocksfoot silage from had a higher content of DM $\left(\mathrm{g} \mathrm{kg}^{-1}\right), \mathrm{CC}\left(\mathrm{g} \mathrm{kg}^{-1} \mathrm{DM}\right)$ and NFE $\left(\mathrm{g} \mathrm{kg}^{-1} \mathrm{DM}\right)$. According to other parameters of silage quality, cocksfoot silage had lower values (Tables 1 and 2).

Addition of cornmeal in cocksfoot (treatments A1 and A2) significantly increased content of DM ( $\left.\mathrm{g} \mathrm{kg}^{-1}\right)$, according to control (A0) (Table 2). Application of cornmeal (treatment A2) in cocksfoot silage caused the reduction 
of $\mathrm{MM}$ content for $6.8 \mathrm{~g} \mathrm{~kg}^{-1} \mathrm{DM}$, further affecting the minimal reduction in $\mathrm{CP}$ content, while the content of CC showed a decrease of $38 \mathrm{~g} \mathrm{~kg}^{-1} \mathrm{DM}$.

Table 2 - Content of nutritive matters of cocksfoot silage

\begin{tabular}{ccccc}
\hline \multirow{2}{*}{ Property } & \multicolumn{3}{c}{ The level cornmeal (\%) } & \multirow{2}{*}{ Average } \\
\cline { 2 - 4 } & $0(\mathrm{~A} 0)$ & $3(\mathrm{~A} 1)$ & $6(\mathrm{~A} 2)$ & \\
\hline $\mathrm{DM}\left(\mathrm{gkg}^{-1}\right)$ & $375^{\mathrm{c}}$ & $381^{\mathrm{b}}$ & $397^{\mathrm{a}}$ & 384.3 \\
$\mathrm{MM}\left(\mathrm{gkg}^{-1} \mathrm{DM}\right)$ & $76.1^{\mathrm{a}}$ & $71.6^{\mathrm{b}}$ & $69.3^{\mathrm{b}}$ & 72.3 \\
$\mathrm{CP}\left(\mathrm{gkg}^{-1} \mathrm{DM}\right)$ & $80.4^{\mathrm{a}}$ & $79.3^{\mathrm{a}}$ & $78.5^{\mathrm{a}}$ & 79.4 \\
$\mathrm{CC}\left(\mathrm{gkg}^{\mathrm{a}} \mathrm{DM}\right)$ & $392.7^{\mathrm{a}}$ & $372.4^{\mathrm{b}}$ & $354.7^{\mathrm{c}}$ & 373.3 \\
$\mathrm{FC}\left(\mathrm{gkg}^{-1} \mathrm{SM}\right)$ & $30.3^{\mathrm{a}}$ & $31.0^{\mathrm{a}}$ & $30.1^{\mathrm{a}}$ & 30.5 \\
$\mathrm{NFE}\left(\mathrm{gkg}^{-1} \mathrm{DM}\right)$ & $419.3^{\mathrm{c}}$ & $442.0^{\mathrm{b}}$ & $467.3^{\mathrm{a}}$ & 442.9 \\
$\mathrm{Ca}\left(\mathrm{gkg}-1 \mathrm{DM}^{\mathrm{a}}\right.$ & $7.8^{\mathrm{a}}$ & $8.0^{\mathrm{a}}$ & $5.3^{\mathrm{b}}$ & 7.0 \\
$\mathrm{P}\left(\mathrm{gkg}^{-1} \mathrm{DM}\right)$ & $2.6^{\mathrm{a}}$ & $2.5^{\mathrm{a}}$ & $2.5^{\mathrm{a}}$ & 2.5 \\
\hline
\end{tabular}

The determined difference between treatments was expressed by the letters a, b, c using the Tukey test at a $5 \%$ probability level.

The effect of treatment on $\mathrm{CF}\left(\mathrm{g} \mathrm{kg}^{-1} \mathrm{DM}\right)$ had no significant effect. As expected addition of corn meal (A2 $467.3 \mathrm{~g} \mathrm{~kg}^{-1} \mathrm{DM}$ ) had the greatest impact on NFE (A0 $419.3 \mathrm{~g} \mathrm{~kg}^{-1} \mathrm{DM}$ ), which differed depending on the treatment by $48 \mathrm{~g}$ $\mathrm{kg}^{-1}$ DM. Concerning $\mathrm{Ca}$ content $\left(\mathrm{g} \mathrm{kg}^{-1} \mathrm{DM}\right)$ treatment $\mathrm{A} 2$ achieved significantly lower values than the treatments $\mathrm{A} 1$ and $\mathrm{A} 0$. While concerning the content of $\mathrm{P}\left(\mathrm{g} \mathrm{kg}^{-1} \mathrm{DM}\right)$ applied treatments showed no significant $(\mathrm{P} \leq 0.05)$ difference. According to Vučković (2004) alfalfa and cocksfoot are often grown in a mixture in less favorable agro-ecological conditions, giving higher yields of quality forage.

Table 3. Nutritive matters content in the cocksfoot and alfalfa silage (50:50\%)

\begin{tabular}{ccccc}
\hline \multirow{2}{*}{ Property } & \multicolumn{3}{c}{ The level cornmeal (\%) } & \multirow{2}{*}{ Average } \\
\cline { 2 - 4 } & $0(\mathrm{~A} 0)$ & $3(\mathrm{~A} 1)$ & $6(\mathrm{~A} 2)$ & \\
\hline $\mathrm{DM}\left(\mathrm{gkg}^{-1}\right)$ & $350^{\mathrm{c}}$ & $360^{\mathrm{b}}$ & $379^{\mathrm{a}}$ & 363.0 \\
$\mathrm{MM}\left(\mathrm{gkg}^{-1} \mathrm{DM}\right)$ & $89.0^{\mathrm{a}}$ & $81.4^{\mathrm{b}}$ & $79.0^{\mathrm{b}}$ & 83.1 \\
$\mathrm{PC}\left(\mathrm{gkg}^{-1} \mathrm{DM}\right)$ & $133.0^{\mathrm{a}}$ & $130.6^{\mathrm{a}}$ & $123.8^{\mathrm{b}}$ & 129.1 \\
$\mathrm{CC}\left(\mathrm{gkg}^{-1} \mathrm{DM}\right)$ & $372.6^{\mathrm{a}}$ & $349.2^{\mathrm{b}}$ & $329.2^{\mathrm{c}}$ & 350.3 \\
$\mathrm{FC}\left(\mathrm{gkg}^{-1} \mathrm{DM}\right)$ & $30.6^{\mathrm{b}}$ & $33.0^{\mathrm{ab}}$ & $37.2^{\mathrm{a}}$ & 33.6 \\
$\mathrm{NFE}\left(\mathrm{gkg}^{-1} \mathrm{DM}\right)$ & $372.6^{\mathrm{c}}$ & $416.5^{\mathrm{b}}$ & $433.9^{\mathrm{a}}$ & 407.7 \\
$\mathrm{Ca}\left(\mathrm{gkg}^{-1} \mathrm{DM}\right)$ & $13.0^{\mathrm{a}}$ & $12.6^{\mathrm{a}}$ & $11.1^{\mathrm{b}}$ & 12.2 \\
$\mathrm{P}\left(\mathrm{gkg}^{-1} \mathrm{DM}\right)$ & $2.6^{\mathrm{b}}$ & $2.6^{\mathrm{b}}$ & $2.8^{\mathrm{a}}$ & 2.7 \\
\hline
\end{tabular}

The determined difference between treatments was expressed by the letters $a, b, c$ using the Tukey test at a $5 \%$ probability level.

As expected silage made from $50 \%$ alfalfa and $50 \%$ cocksfoot also contained average values nutrients compared to silage made only from alfalfa or only from 
cocksfoot (Table 3 ). The obtained average values indicate a wide possibility of use of $50 \%$ alfalfa and $50 \%$ cocksfoot silage in the diet of ruminants.

According to the obtained values (Table 1) in dairy cows feeding due to the need for increased protein content preference could be given to alfalfa silage. Whereas, in beef cattle feeding preference should be given to cocksfoot silage with greater application of cornmeal due to the increased content of carbohydrate feeding (Table 2).

\section{Conclusion}

Silage made from alfalfa as an animal feed has a high content of crude protein (185.8 $\mathrm{g} \mathrm{kg}^{-1} \mathrm{DM}$ - treatment A0) compared to silage of cocksfoot (SP $80.4 \mathrm{~g} \mathrm{~kg}^{-1} \mathrm{DM}$ ) and silage of mixture of $50 \%$ alfalfa, $50 \%$ cocksfoot (SP $133.0 \mathrm{~g}$ $\mathrm{kg}^{-1} \mathrm{DM}$ ). The addition of corn meal (treatment A2 in relation to treatment A0) significantly $(\mathrm{p} \leq 0.05)$, increased carbohydrate value in alfalfa silage (BEM 73.3 $\mathrm{g} \mathrm{kg}^{-1} \mathrm{DM}$ ), cocksfoot (BEM $48.0 \mathrm{~g} \mathrm{~kg}^{-1} \mathrm{DM}$ ) and their mixture (BEM $61.3 \mathrm{~g} \mathrm{~kg}^{-1}$ DM).

\section{Acknowledgements}

The work is part of the research project TR-31092, funded by the Ministry of Science and Technological development of the Republic of Serbia.

\section{References}

Carino, H. (1988): L'utilisation d'additifs dans les ensilages. Karma i karmljenjije seljskohazjajstvennih zivotnih. Moskva, 4: 5.

Đorđević, N., Grubić, G., Adamović, M. (2000): Influence of wilting, inoculant and carbohydrate additives on lucerne silagequality. Abstract $51^{\text {th }}$ Annual Meeting of EAAP, Hague, 168.

Handžić, R., Maksimović, D., Branković, S., Đurđev, V., Jovanović, S. (1972): Uticaj dodavanja različitih koncentratnih krmiva na probavljivost i bilans hranljivih materija u složenim lucerkinim silažama. Zbornik radova Jugoslovenskog simpozijuma iz stočarstva, Poljoprivredni fakultet, Zemun, 256-267.

McDonald, P., Henderson, A. R., Heron, S. J. E. (1991): The biochemistry of silage, Marlow, UK, 340.

Moga, I., Schitea, M. (2005): Tehnologii moderne de producere a seminţelor la plantele furajere. Ed. Ceres, Bucuresti: 23-54.

Pavličević, A., Adamović, M., Nešić, S., Nikolić, P., Stojićević, LJ. (1999): Efikasnost siliranja lucerke sa dodatkom kukuruza i bakterijskoenzimskog inokulanta. Zbornik naučnih radova PKB INI Agroekonomik, Beograd, 5(1): 457-465. 
Probert, R. J., Smith, R. D., Birch, P. (1986): Germination responses to light and alternating temperatures in European populations of Dactylis glomerata L. V. The principal components of the alternating temperature requirement. New Phytologist, 102: 133-142.

Ružić-Muslić, D., Petrović, M., Bijelić, Zorica, Pantelić, V., Perišić, P, Bogdanović, V. (2011): Traditional Production and Characteristics of Sjenica Cheese and Pirot Kachkaval. Bulgarian Journal of Agricultural Science, 17(5): 664-672.

Samuil, C., Vintu, V., Sirbu, C, Surmei, M. G. (2011): Behaviour of fodder mixtures with alfalfa in north-eastern Romania. Romanian Agricultural Research, 29: 227-235.

Šćiban, M., Kukić, D., Ivetić, D., Prodanović, J., Antov, M. (2013): Mogućnost primene tretiranih repinih rezanaca iz procesa proizvodnje bioetanola kao hrane za stoku. Journal on Processing and Energy in Agriculture, 17(3): 124-126.

Stanisavljević, R., Beković, D. (2012): Uticaj ekoloških uslova na prinos semena lucerke, 139-172. U Monog: Unapređenje gajenja krmnih biljaka na oranicama. Zbornik radova XVII Savetovanje o biotehnologiji, Agronomski fakultet, Čačak, 1-330.

Stje panović, M., P opović, S . (2009): Alfalfa seed production. Proceedings, Ed. S. Popović and M. Stjepanović, University of Osijek, Faculty of Agriculture in Osijek and Agricultural Institute Osijek, 221-262.

Terzić, Dušanka, Radosavljević, Milica, Milašinović-Š́eremešić, Marija, Pajić, Zorica, Todorović G., Stanković, G. (2013): Biomass yield and quality of silage maize hybrids. Proceedings of the $3^{\text {rd }}$ International conferences sustainable postharvest and food technologies-INOTEP 2013 and $25^{\text {th }}$ and National conference processing and energy in agriculture -PTEP, April $21^{\text {st }}-26^{\text {th }}, 2013$, Vrnjačka Banja, Serbia, 224-228.

Vlahova, M., Stefanova, G., Petkov, P., Barbulova, A., Petkova, D., Kalushkov, P., Atanassov, A. (2005): Genetic mod ification of alfalfa (Medicago sativa L.) for quality improvement and production of novel compounds. Biotechnol. Sofia, Bulgaria, Eq. 19: 56-62.

Vučk ovi ć, S . (2004): Travnjaci. Poljoprivredni fakultet, univerzitet Beograd, 1-506. 


\title{
PRIMENA KUKURUZNE PREKRUPE PRI SILIRANJU LUCERKE, JEŽEVICE I NJIHOVE SMEŠE
}

\author{
Jasmina Knežević, M. Aksić, S. Ćirić \\ Univerzitet u Prištini, Poljoprivredni fakultet $u$ Lešku \\ V.Stevović, D. Tomić \\ Univerzitet u Kragujevcu, Agronomski fakultet u Čačku \\ R. Stanisavljević
}

Institut za zaštitu bilja i životnu sredinu, Beograd

\section{Rezime}

Jedno od rešenja za ekonomično korišćenje lucerke i ježevice je spravljanje silaže. Međutim ove biljne vrste se teško mogu konzervisati bez odgovarajućih dodataka. Cilj ovih ispitivanja bio je određivanje uticaja kukuruzne prekrupe na kvalitet silaže od lucerke, ježevice i njihove smeše (50\% lucerka, $50 \%$ ježevica). Ispitivanje je sprovedeno na krmi: lucerke (Medicago sativa L.) sorte Kruševačka 22, ježevice (Dactilys glomerata L.) sorte Kruševačka 40 i njihove smeše (50\% lucerka i 50\% ježevica). Košenje obe vrste obavljeno je u fazi kada je 1/3 do 1/5 biljaka bilo u cvetu kod lucerke odnosno u klasanju kod ježevice. Kukuruzno zrno je mleveno na mlinu sa sitima ø $2 \mathrm{~mm}$, zatim je mešano sa seckanom krmom lucerke, ježevice i smeše u količini: 6\% (tretman A2), 3\% (tretman A1), i bez prekrupe (kontrola A0). Nakon šest meseci utvrđen je kvalitet silaže. Dodatak kukuruzne prekrupe je prema osnovnim pokazateljima kvaliteta silaža imao značajan uticaj na promenu kvaliteta silaže lucerke ježevice i smeše. Evidentno je da dodavanje kukuruzne prekrupe značajno utiče na povećanje energetske vrednosti (pre svega sadražaja BEM) u silaži svih ispitivanih vrsta.

Ključne reči: silaža, lucerka, ježevica, kukuruzna prekrupa, kvalitet. 